\title{
Lactic Acid Bacteria against Listeria monocytogenes
}

\author{
Juliana Sousa Bogéa ${ }_{\oplus}^{1}$, Luciane Manto ${ }_{\oplus}^{2}$, Jucilene Sena dos Santos ${ }^{1}$, Lara Franco dos Santos ${ }_{\oplus}^{2}$, \\ Franciele Maria Gottardo ${ }_{(}^{1}$, Laura Beatriz Rodrigues ${ }_{(}^{1,2}$ \& Luciana Ruschel dos Santos ${ }_{\odot}^{1,2}$
}

\begin{abstract}
Background: Listeria monocytogenes is a pathogenic bacterium that can contaminate food and cause public health problems due its ability to form biofilms and resistance to sanitizers, it is responsible for sanitary and economic losses in food producing establishments. The difficulties in controlling biofilms and increasing resistance to traditional antibacterial agents is motivating studies of alternative potential biological agents for the control of pathogenic biofilms, among which lactic acid bacteria (LABs) are included. The objective of this work was to evaluate the activity of LABs against Listeria monocytogenes biofilm formation on polystyrene plates, a surface commonly used in the food industry.

Materials, Methods \& Results: Lyophilized commercial strains of Bifidobacterium animalis, Lactobacillus fermentum, Lactobacillus plantarum, Lactobacillus salivaris and Lactobacillus acidophilus were used. The strain of Listeria monocytogenes (L4) was isolated from polystyrene mats from a poultry slaughterhouse cutting room and demonstrated the ability to attach to microplates and resistance to sanitizers (sodium hypochlorite and hydrogen peroxide) at all times, temperatures and tested surfaces. The antimicrobial activity of LABs was evaluated by the agar diffusion method. The LABs that presented action on Listeria monocytogenes were selected for the inhibition and/or removal of biofilms in microplates, and all experiments were carried out in triplicate. Only Bifidobacterium animalis and Lactobacillus plantarum demonstrated action against Listeria monocytogenes in the agar diffusion assays and were selected for inhibition and competition assays. Furthermore, competition of LABs against Listeria monocytogenes adhesion was evaluated. There was no significant difference between LABs and L. monocytogenes, alone or in combination, at temperatures of $30^{\circ} \mathrm{C}$ and $37^{\circ} \mathrm{C}$ in the Listeria monocytogenes inhibition assays on polystyrene surface. The lactic acid bacteria evaluated did not demonstrate inhibition of L. monocytogenes adhesin testes with optical density visualization, however, it was possible to identify a reduction in L. monocytogenes counts with the application of Bifidobacterium animals and Lactobacillus plantarum in the testes of competition against biofilm formation. In competition tests Bifidobacterium animalis and Lactobacillus plantarum have an injunction in Listeria monocytogenes, indicating that these lactic acid bacteria can retard Listeria biofilm formation on polystyrene surfaces and thus help control the pathogen in the food industry.

Discussion: A potential mechanism to control biofilm adhesion and formation of pathogens for nutrients and fixation on surfaces, multiplication factors and surfaces are a challenge in controlling biofilms of pathogenic microorganisms, alternative measures to traditional methods for inactivating pathogens and biofilm formers bacteria are necessary. In this sense, lactic acid bacteria generate high levels of bacteriocin and are effective in inhibiting the biofilm of pathogenic bacteria, however, our study did not reveal this. We verified that Bifidobacterium animalis and Lactobacillus plantarum have an inhibitory action on Listeria monocytogenes, indicating that these lactic acid bacteria can be used to delay the formation of biofilms by Listeria on polystyrene surfaces, helping to control this pathogen in food industry.
\end{abstract}

Keywords: control of biofilm, pathogenic bacteria, food industry, polystyrene surface, FTDs. 


\section{INTRODUCTION}

Listeria monocytogenes is a pathogenic bacterium causing listeriosis, a food-transmitted disease (FTDs) that can cause septicemia, meningitis, and even death in the most severe cases. If contracted during pregnancy, L. monocytogenes can result in miscarriage, premature birth, a severe infection of the newborn, or even stillbirth [11,42]. Most outbreaks are associated with the ingestion of ready-to-eat foods based on meat and dairy products that do not undergo cooking or microbial inactivation for consumption $[5,21,37]$.

Other characteristics of the agent are multiplication under refrigeration temperatures, high tolerance to disinfectants, and the ability to form biofilms $[9,16]$. Biofilms are a set of living microorganisms surrounded by an extracellular polymer matrix (EPS) that can become fixed to and multiply on any surface, being difficult to eliminate due to the protection conferred by the EPS and varying levels of resistance to sanitizers [11,12,33].

The control of Listeria biofilms is a challenge for the food industry, using traditional methods, an alternative to these methods would be the application of lactic acid bacteria (LABs) [34]. LABs care a group of microorganisms capable of fermenting with other products, controlling the multiplication of microorganisms by reducing the $\mathrm{pH}$ and producing inhibitory compounds [30].

The application of LABs to neutralize the proliferation of other bacteria on contact surfaces is based on the principle of competitive exclusion, where LABs with biofilm formation capacity can limit the multiplication of pathogens through competition for nutrients, production of antimicrobial substances, and physicochemical changes of surfaces $[10,17,19,24,25,37]$.

\section{MATERIALS AND METHODS}

Lactic Acid Bacteria (LABs) and Listeria monocytogenes

Lyophilized commercial strains of Bifidobacterium animalis, Lactobacillus fermentum, L. plantarum, L. salivaris and L. acidophilus were used. The strains were reactivated in MRS Broth ${ }^{1}$ at $30^{\circ} \mathrm{C}$ for $18 \mathrm{~h}$, and sown in MRS Agar ${ }^{1}$ under the same conditions. The isolates were kept at $-80^{\circ} \mathrm{C}$ in MRS broth supplemented with $20 \%$ (v/v) of sterile glycerol.

The strain of Listeria monocytogenes (L4) was isolated from polystyrene mats from a poultry slaugh- terhouse cutting room [28] and demonstrated the ability to attach to microplates and resistance to sanitizers (sodium hypochlorite and hydrogen peroxide) at all times $(0,4,12$, and $24 \mathrm{~h})$, temperatures $\left(42 \pm 1^{\circ} \mathrm{C}\right.$, $36 \pm 1^{\circ} \mathrm{C}, 25 \pm 1^{\circ} \mathrm{C}, 9 \pm 1^{\circ} \mathrm{C}$, and $3 \pm 1^{\circ} \mathrm{C}$ ) and tested surfaces (stainless steel, polyethylene, and polystyrene) (unpublished data). L. monocytogenes ATCC7644 was used as a control. Both isolates were stored at $-20^{\circ} \mathrm{C}$ in Broth Brain Heart Infusion (BHI)2 with $20 \%$ glycerol and were reactivated in $\mathrm{BHI}$ broth for $18 \mathrm{~h}$ to $37^{\circ} \mathrm{C}$ with confirmation in Triple Sugar Iron (TSI), Lysine Iron Agar (LIA), indole, urea, citrate, nitrate, methyl red, ramanose, and mannitol ${ }^{2}$.

\section{Preparation of the LABs free-cells supernatants}

For the preparation of the free-cells supernatants, the LABs were incubated in MRS Broth at $37^{\circ} \mathrm{C}$ for $24 \mathrm{~h}$. Next, the supernatant of each culture was obtained by centrifugation at $16128 \mathrm{~g}$ for $15 \mathrm{~min}$, neutralized with $1 \mathrm{M} \mathrm{NaOH} \mathrm{pH} \mathrm{6.5,} \mathrm{filtered} \mathrm{in} \mathrm{a} 0.22$ $\mu \mathrm{m}$ filter and partially purified [14]. The cell suspension of the LABs was concentrated in a centrifuge at $448 \mathrm{~g}$ for $6 \mathrm{~min}$. The supernatant and bacteria suspended in MRS broth were removed.

Inhibition assays of Listeria monocytogenes by LABs in the agar diffusion method

The antimicrobial activity of LABs was evaluated by the agar diffusion method [3]. L. monocytogenes suspensions equivalent to 0.5 of the MacFarland scale were sown in BHI agar and after $5 \mathrm{~min}, 8 \mathrm{~mm}$ orifices were punctured with a sterile punch and a volume of $80 \mu \mathrm{L}$ of the LABs supernatant (106 CFU/ $\mu \mathrm{L})$ was inoculated. Tetracycline discs $(30 \mu \mathrm{g})^{3}$, were used as a positive control. The plates were incubated at $37^{\circ} \mathrm{C}$ and after $24 \mathrm{~h}$ the diameters were measured in millimeters. The LABs that presented action on $L$. monocytogenes were selected for the inhibition and/ or removal of biofilms in microplates. All experiments were carried out in triplicate.

\section{Polystyrene microplate assays}

Only Bifidobacterium animalis and Lactobacillus plantarum demonstrated action against Listeria monocytogenes in the agar diffusion assays and were selected for inhibition and competition assays [35]. To evaluate the inhibition of Listeria on the polystyrene surface, $100 \mu \mathrm{L}$ of the suspension of LABs was incubated individually at $30^{\circ} \mathrm{C}$ and $37^{\circ} \mathrm{C}$ for 48 
h. After 24 h, $200 \mu \mathrm{L}$ of LABs were added individually, and after $48 \mathrm{~h}, 100 \mu \mathrm{L}$ of Listeria cultures. The plates were incubated for $24 \mathrm{~h}$ at $30^{\circ} \mathrm{C}$ and $24 \mathrm{~h}$ at $37^{\circ} \mathrm{C}$, totaling $48 \mathrm{~h}$ of incubation for Listeria. LABs were grown individually in MRS broth for 18-24 h at $37^{\circ} \mathrm{C} \pm 1^{\circ} \mathrm{C}$ and adjusted to Mac Farland scale 1 $\left(3.0 \times 10^{8} \mathrm{CFU} / \mu \mathrm{L}\right)$.

To evaluate the competition of LABs in the face of the adhering of L. monocytogenes, $200 \mu \mathrm{L}$ of bacteria suspension were inoculated in each well and $200 \mu \mathrm{L}$ of the suspension of each LABs, individually. As a positive control, $200 \mu \mathrm{L}$ of the suspension of LABs was added and as a negative control $200 \mu \mathrm{L}$ of sterile MRS. The plates were incubated at $30^{\circ} \mathrm{C}$ and $37^{\circ} \mathrm{C}$ for $48 \mathrm{~h}$, the wells rinsed 3 times with $200 \mu \mathrm{L}$ of sterile $\mathrm{NaCL} 0.85 \%$ and dried at room temperature. Next, the bacteria were fixed with 250 $\mu \mathrm{L}$ of methanol p.a., which was removed after 15 min and the plates dried at room temperature. After being flushed with $200 \mu \mathrm{L}$ of $2 \%$ Hucker violet crystal for $5 \mathrm{~min}$, washed in running water and dried at room temperature, the absorbance reading was performed before and after the addition of 250 $\mu \mathrm{L}$ of glacial acetic acid $33 \%$, in ELISA reader ${ }^{4}$ at 550 and $595 \mathrm{~nm}$.

To evaluate the viable number of microorganisms, the wells of the plates were washed 3 times and scraped with a platinum handle. The suspensions obtained were transferred to sterile tubes, and dilutions were performed in $0.85 \%$ saline solution $(\mathrm{w} / \mathrm{v})$, followed by sowing in BHI Agar and Palcam $\mathrm{Agar}^{3}$ to L. monocytogenes by plate drop method (inoculation of 5 drops of $10 \mu \mathrm{L}$ of each dilution). The plates were incubated at $37^{\circ} \mathrm{C}$ for $24-48 \mathrm{~h}$, the bacterial counts performed and the percentage of inhibition and competition was calculated [13] as follows:

Biofilm Reduction $\%=\left(\mathrm{OD}_{\text {Control }}-\mathrm{OD}_{\text {Treatment }}\right) \div \mathrm{OD}_{\text {Control }} \times 100 \%$

Statistical analysis

The mean of the data in triplicate of the experiments was analyzed by ANOVA, and the difference between the means was evaluated by the Tukey test with a $95 \%$ confidence interval $(P<0.05)$ in Statistic 7.

\section{RESULTS}

The results of action of LABs are shown in Figure 1. Although the LABs evaluated in our study did not show inhibition of Listeria adhesin trials with measurement of optic density, it was possible to iden- tify a reduction in $L$. monocytogenes count with the application of Bifidobacterium animals and Lactobacillus plantarum in the competition trials against the formation of biofilms.

In our work, the results of the competition trials showed that Bifidobacterium animalis and Lactobacillus plantarum have an injunction on Listeria monocytogenes, indicating that these lactic acid bacteria can be used to delay the formation of biofilms by bacteria on polystyrene surfaces and, thus, assist in the control of this pathogen in the food industry.

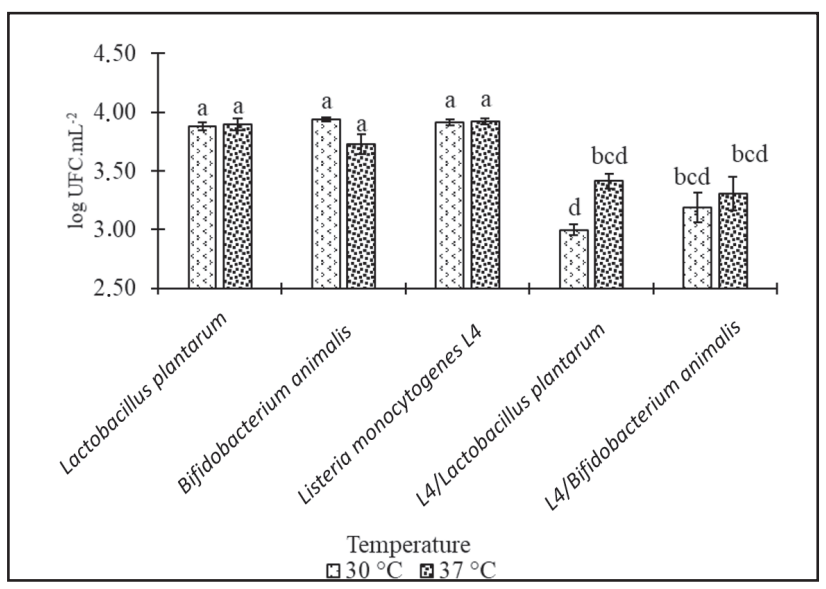

Figure 1. Quantification of biofilm in competition trials between acid lactic bacteria and Listeria monocytogenes in polystyrene plates. Means followed by the same letters do not differ from each other by the Tukey test $(P<0.05)$.

\section{DISCUSSION}

There was no significant difference between LABs and L. monocytogenes, alone or in combination, at temperatures of 30 and $37^{\circ} \mathrm{C}(P<0.05)$ in the Listeria adept inhibition assays on polystyrene surface. These results differ from Lactobacillus plantarum generate high concentrations of bacteriocin and was effective at inhibiting biofilm of Listeria monocytogenes [34] as well as Lactobacillus plantarum and L. fermentum as capable of adhering in polystyrene and inhibiting biofilms of other pathogens (Pseudomonas aeruginosa and Salmonella Typhimurium) [2].

Other studies evaluating the effects of LABs against Listeria monocytogenes biofilms on different surfaces also contradict our results, when testing stainless steel surfaces $\left(24 \mathrm{~h}\right.$ at $\left.30^{\circ} \mathrm{C}\right)$ but reporting inhibition by the superior by Lactobacillus curvatus (2.17 $\left.\log \mathrm{CFU} / \mathrm{cm}^{2}\right)$ than by L. plantarum $(1.45 \mathrm{log}$ $\mathrm{CFU} / \mathrm{cm}^{2}$ ) [19]. 
Listeria monocytogenes can be detected in several environments, including soil, water, vegetation, drains, animal and human feces, among others. It can adhere and form biofilms that are aggregates composed of one or more living microorganisms organized and linked to each other, surrounded by extracellular polymeric substances (EPS) and other substances. These microorganisms after adhesion on surfaces such as stainless steel, glass, plastics, and others, form microcolonies and produce EPS allowing the maturation of the biofilm that over time become permanent reservoirs of pathogenic bacteria whose penetration of sanitizing agents is inhibited by the developed resistance that is superior to planktonic cells. In this way, pathogenic bacteria such us L. monocytogenes can persist in industrial processing environments, especially in equipment and food contact surfaces, and cause continuous contamination of food products that are handled after heat treatment $[1,4,11,20,22,27]$.

Strains of the bacterium isolated from food products have shown resistance to common antibiotics such as penicillin, ampicillin, oxacillin, clindamycin, and tetracycline confirming the trend of resistance to a wide range of antimicrobial agents. Antimicrobial resistance of L. monocytogenes isolates from food has been described in beef, pork, chicken, fish, and dairy production chains and this fact may have serious consequences for public health where future outbreaks may be more difficult to control $[7,15,23,29,40]$.

In our work, we selected Lactobacillus plantarum for the trials with Listeria biofilms because this LAB is cited as effective against this pathogen, which was not confirmed in our studies of inhibition of the disease. In this context, Lactobacillus curvatus, $L$. fermentum and L. delbrueckii inhibited polystyrene listerias biofilms with $24 \mathrm{~h}$ of multiplication, which can be attributed to the potential for adhesion according to the type of LAB evaluated [6]. This hypothesis can be corroborated by suitability and formation of biofilms by Bifidobacterium and Lactobacillus (including Bifidobacterium animalis and Lactobacillus plantarum used in our study) on stainless steel, glass, and polycarbonate surfaces was superior by LABs Bifidobacterium infantis and Lactobacillus reuteri and in less time the other surfaces teste [32].

In addition to the characteristic properties of each species of LAB, the surface material is an important factor in the adhesion and biofilm formation of Lis- teria monocytogenes [9] when the bacteria support on surfaces commonly used in food processing areas such as aluminum, rubber, stainless steel, polycarbonate, and polypropylene. The polystyrene surface mimics some of the plastic materials used in food processing plants and presents a good in vitro stimulation [26] such as polyethylene of cutting plates and the polyurethane present in conveyor belts of poultry slaughterhouses.

When evaluating the competition in polystyrene plates, the LABs in the study interfered with the performance of L. monocytogenes, with no significant difference in antimicrobial activity between Lactobacillus plantarum and Bifidobacterium animals. Our results agree with studies that showing the influence of Lactobacillus sakei on the adhesion of Listeria monocytogenes on stainless steel surfaces [36]. Another competition test used Lactobacillus paraplantarum showed a significant reduction in Listeria monocytogenes in stainless steel (2.4 $\log$ in 24 and $48 \mathrm{~h}$ and $1.86 \log$ in $72 \mathrm{~h}$ ) [38]. The temperature, nutrient availability and variability among strains are important factors in the formation of L. monocytogenes biofilm in polystyrene plates [9].

Competition for nutrients and fixation on surfaces is the mechanism with the greatest potential to control the adhesion and formation of biofilms of pathogenic microorganisms $[8,14,37]$. The multiplication factors and the surfaces are a challenge of controlling biofilms of pathogenic microorganisms [18,31,39]. The practical application of LABs can be evaluated with the reduction of biofilms of L. monocytogenes, Salmonella spp. and Escherichia coli $\mathrm{O} 157: \mathrm{H} 7$ with probiotic characteristics and without risk to the consumer, using strains of Bacteriocin-producing Lactobacillus (L. lactis, L. sakei, and L. curvatus) and non-producers (Lactococcus lactis subesp. lactis, Lactobacillus helveticus, L. casei and Weissella viridescens) [12]. Furthermore, the reduction of Listeria monocytogenes in poultry processing plants indicates the potential of the control strategy with lactic acid bacteria [41].

\section{CONCLUSION}

In our work, the results of the competition trials showed that Bifidobacterium animalis and Lactobacillus plantarum have an injunction on Listeria monocytogenes, indicating that these lactic acid bacteria can be used to delay the formation of biofilms by bacteria on polystyrene surfaces and, thus, assist in the control of this pathogen in the food industry. 
MANUFACTURERS

${ }^{1}$ Difco Laboratories Incorporated. Detroit, MI, USA.

${ }^{2}$ Merck KGaA. Darmstadt, Germany.

${ }^{3}$ Laborclin Produtos para Laboratórios Ltda. Pinhais, PR, Brazil.

${ }^{4}$ Anthos Labtec Instruments. Salzburg, Austria.
Declaration of interest. The authors report no conflicts of interest. The authors alone are responsible for the content and writing of the paper.

\section{REFERENCES}

1 Allen K.J., Wałecka-Zacharska E., Chen J.C., Katarzyna K.P., Devlieghere F., Van Meervenne E., Osek J., Wieczorek K. \& Bania J. 2016. Listeria monocytogenes - An examination of food chain factors potentially contributing to antimicrobial resistance. Food Microbiology. 54: 178-189. DOI: 10.1016/j.fm.2014.08.006

2 Aoudiaa N., Rieua A., Briandet R., Deschamps J., Chluba J., Jego G., Garrido C. \& Guzzo J. 2016. Biofilms of Lactobacillus plantarum and Lactobacillus fermentum: Effect on stress responses, antagonistic effects on pathogen growth and immunomodulatory properties. Food Microbiology. 53: 51-59. DOI: 10.1016/j.fm.2015.04.009

3 Balouiri M., Sadiki M. \& Ibnsouda S.A. 2016. Methods for in vitro evaluating antimicrobial activity: A review. Journal of Pharmaceutical Analysis. 6(2): 71-79. DOI: 10.1016/j.jpha.2015.11.005

4 Bridier A., Sanchez-Vizuete P., Guilbaud M., Piard J.C., Naïtali M. \& Briandet R. 2015. Biofilm-associated persistence of food-borne pathogens. Food Microbiology. 45: 167-178. DOI: 10.1016/j.fm.2014.04.015

5 Buchanan R.L., Gorris L.G.M., Hayman M.M., Jackson T.C. \& Whiting R.C. 2017. A review of Listeria monocytogenes: An update on outbreaks, virulence, dose-response, ecology, and risk assessments. Food Control. 75: 1-13. DOI: 10.1016/j.foodcont.2016.12.016

6 Camargo A.C., Todorov S.D., Chihib N.E., Drider D. \& Nero L.A. 2018. Lactic acid bacteria (LAB) and their bacteriocins as alternative biotechnological tools to control Listeria monocytogenes biofilms in food processing facilities. Molecular Biotechnology. 60: 712-726. DOI:10.1007/s12033-018-0108-1

7 Caruso M., Fraccalvieri R., Pasquali F., Santagada G., Latorre L.M., Difato L.M., Miccolupo A., Normanno G. \& Parisi A. 2020. Antimicrobial susceptibility and multilocus sequence typing of Listeria monocytogenes isolated over 11 years from food, humans, and the environment in Italy. Foodborne Pathogens and Disease. 17: 284-294. DOI: 10.1089/fpd.2019.2723

8 Collado M.C., Meriluoto J. \& Salminen S. 2008. Adhesion and aggregation properties of probiotic and pathogen strains. European Food Research and Technology. 226: 1065-1073. DOI: 10.1007/s00217-007-0632

9 Dygico L.K., Gahan C., Grogan H. \& Burgess C. 2019. The ability of Listeria monocytogenes to form biofilm on surfaces relevant to the mushroom production environment. International Journal of Food Microbiology. 317: 108385. DOI: $10.1016 /$ j.ijfoodmicro.2019.108385

10 Falagas M.E. \& Makris G.C. 2009. Probiotic bacteria and biosurfactants for nosocomial infection control: a hypothesis. Journal of Hospital Infection. 71(4): 301-306. DOI: 10.1016/j.jhin.2008.12.008

11 Gao Z., Zhong W., Chen K., Tang P. \& Guo J. 2020. Chemical composition and anti-biofilm activity of essential oil from Citrus medica L. var. sarcodactylis Swingle against Listeria monocytogenes. Industrial Crops and Products. 144: 112036. DOI: 10.1016/j.indcrop.2019.112036

12 Gómez N.C., Ramiro J.M.P., Quecan B.X.V. \& Melo Franco B.D.G. 2016. Use of potential probiotic lactic acid bacteria (LAB) biofilms for the control of Listeria monocytogenes, Salmonella Typhimurium and Escherichia coli O157:H7 biofilms formation. Frontiers in Microbiology. 7(863): 1-15. DOI: 10.3389/fmicb.2016.00863

13 Gong C. \& Jiang X. 2017. Application of bacteriophages to reduce Salmonella attachment and biofilms on hard surfaces. Poultry Science. 96(6): 1838-1848. DOI: 10.3382/ps/pew463

14 Grosu-Tudor S., Stancu M., Pelinescu D. \& Zamfir M. 2014. Characterization of some bacteriocins produced by lactic acid bacteria isolated from fermented foods. World Journal of Microbiology and Biotechnology. 30: 2459-2469. DOI: $10.1007 / \mathrm{s} 11274-014-1671-7$

15 Gücükoğlu A., Çadirci Ö., Terzi Gülel G., Uyanik T. \& Kanat S. 2020. Serotyping and antibiotic resistance profile of Listeria monocytogenes isolated from organic chicken meat. Kafkas Universitesi Veteriner Fakultesi Dergisi. 26: 499-505. DOI: $10.9775 / \mathrm{kvfd} .2019 .23638$ 
16 Hansen L.T. \& Vogel B.F. 2011. Desiccation of adhering and biofilm Listeria monocytogenes on stainless steel: Survival and transfer to salmon products. International Journal of Food Microbiology. 146(1): 88-93. DOI: 10.1016/j. ijfoodmicro.2011.01.032

17 Hibbing M.E., Fuqua C., Parsek M.R. \& Peterson S.B. 2010. Bacterial competition: surviving and thriving in the microbial jungle. Nature Reviews Microbiology. 8: 15-25. DOI: 10.1038/nrmicro2259

18 Hossain M. I., Sadekuzzaman M. \& Ha S.D. 2017. Probiotics as potential alternative biocontrol agents in the agriculture and food industries: A review. Food Research International. 100: 63-73. DOI: 10.1016/j.foodres.2017.07.077

19 Hossain M.I., Mizan M.F.R., Ashrafudoulla M., Nahar S., Joo H.J., Jahid I.K., Park S.H., Kim K.S. \& Ha S.D. 2020. Inhibitory effects of probiotic potential lactic acid bacteria isolated from kimchi against Listeria monocytogenes biofilm on lettuce, stainless-steel surfaces, and MBEC ${ }^{\text {TM }}$ biofilm device. LWT-Food Science and Technology. 118: 108864. DOI: 10.1016/j.lwt.2019.108864

20 Kocot A.M. \& Olszewska M.A. 2017. Biofilm formation and microscopic analysis of biofilms formed by Listeria monocytogenes in a food processing context. LWT - Food Science \& Technology. 84: 47-57. DOI: 10.1016/j.lwt.2017.05.042.

21 Leong D., NicAogáin K., Luque-Sastre L., McManamon O., Hunt K., Alvarez-Ordóñez A., Scollard J., Schmalenberger A., Fanning S. \& O'Byrne C. 2017. A 3-year multi-food study of the presence and persistence of Listeria monocytogenes in 54 small food businesses in Ireland. International Journal of Food Microbiology. 249: 18-26. DOI: 10.1016/j.ijfoodmicro.2017.02.015

22 Martín B., Perich A., Gómez D., Yangüela J., Rodríguez A., Garriga M. \& Aymerich T. 2014. Diversity and distribution of Listeria monocytogenes in meat processing plants. Food Microbiology. 44: 119-127. DOI: 10.1016/j. fm.2014.05.014

23 Olaimat A.N., Al-Holy M.A., Shahbaz H.M., Al-Nabulsi A.A., Abu Ghoush M.H., Osaili T.M., Ayyash M.M. \& Holley R.A. 2018. Emergence of antibiotic resistance in Listeria monocytogenes isolated from food products: A comprehensive review. Comprehensive Reviews in Food Science and Food Safety. 17: 1277-1292. DOI: 10.1111/15414337.12387

24 Pérez-Ibarreche M., Castellano P. \& Vignolo G. 2014. Evaluation of anti-Listeria meat borne Lactobacillus for biofilm formation on selected abiotic surfaces. Meat Science. 96(1): 295-303. DOI: 10.1016/j.meatsci.2013.07.010

25 Pérez-Ibarreche M., Castellano P., Leclercq A. \& Vignolo G. 2016. Control of Listeria monocytogenes biofilms on industrial surfaces by the bacteriocin-producing Lactobacillus sakei CRL1862. FEMS Microbiology Letters. 363(12): 1-6. DOI: $10.1093 /$ femsle/fnw118

26 Piras F., Fois F., Consulti S.G., Mazza R. \& Mazzette R. 2015. Influence of temperature, source, and serotype on biofilm formation of Salmonella enterica isolates from pig slaughterhouses. Journal of Food Protection. 78(10): 18751878. DOI: 10.4315/0362-028X.JFP-15-085

27 Puga C.H., SanJose C. \& Orgaz B. 2016. Biofilm development at low temperatures enhances Listeria monocytogenes resistance to chitosan. Food Control. 65: 143-151. DOI: 10.1016/j.foodcont.2016.01.012

28 Rodrigues L.B., Santos L.R., Rizzo N.N., Tagliari V.Z., Trenhago G., Oliveira A.P., Ferreira D., Pilotto F. \& Nascimento V.P. 2013. Salmonella and Listeria from stainless steel, polyurethane and polyethylene surfaces in the cutting room of a poultry slaughterhouse. Acta Scientiae Veterinariae. 41: 1164. 7p.

29 Rugna G., Carra E., Bergamini F., Franzini G., Faccini S., Gattuso A., Morganti M., Baldi D., Naldi S., Serraino A., Piva S., Merialdi G. \& Giacometti F. 2021. Distribution, virulence, genotypic characteristics and antibiotic resistance of Listeria monocytogenes isolated over one-year monitoring from two pig slaughterhouses and processing plants and their fresh hams. International Journal of Food Microbiology. 336: 108912. DOI: 10.1016/j.ijfoodmicro.2020.108912

30 Salomskiene J., Jonkuviene D., Macioniene I., Abraitiene A., Zeime J., Repeckiene J. \& Vaiciulyte-Funk L. 2019. Differences in the occurrence and efficiency of antimicrobial compounds produced by lactic acid bacteria. European Food Research and Technology. 245: 569-579. DOI: 10.1007/s00217-018-03227-3

31 Silva C.C.G, Silva S.P.M. \& Ribeiro S.C. 2018. Application of bacteriocins and protective cultures in dairy food preservation. Frontiers in Microbiology. 9: 594. DOI: 10.3389/fmicb.2018.00594

32 Speranza B., Liso A. \& Corbo M.R. 2018. Use of design of experiments to optimize the production of microbial probiotic biofilms. Peer J. 6: e4826. DOI: 10.7717/peerj.4826

33 Srey S., Jahid I.K. \& Ha S.D. 2013. Biofilm formation in food industries: A food safety concern. Food Control. 31(2): 572-585. DOI: 10.1016/j.foodcont.2012.12.001 
34 Todorov S.D., Paula O.A.L., Camargo A.C., Lopes D.A. \& Nero L.A. 2018. Combined effect of bacteriocin produced by Lactobacillus plantarum ST8SH and vancomycin, propolis or EDTA for controlling biofilm development by Listeria monocytogenes. Revista Argentina de Microbiología. 50(1): 48-55. DOI: 10.1016/j.ram.2017.04.011

35 Webber B., Oliveira A.P., Pottker E.S., Daroit L., Levandowski R., Santos L.R., Nascimento V.P. \& Rodrigues L.B. 2019. Salmonella Enteritidis forms biofilm under low temperatures on different food industry surfaces. Ciência Rural. 49(7): 1-9. DOI: 10.1590/0103-8478cr20181022.

36 Winkelströter L.K., Gomes B.C., Thomaz M.R.S., Souza V.M. \& Martinis E.C.P. 2011. Lactobacillus sakei and its bacteriocin influence adhesion of Listeria monocytogenes on stainless steel surface. Food Control. 22: 1404-1407. DOI: 10.1016/j.foodcont.2011.02.021

37 Winkelströter L.K., Reis F.B., Silva E.P., Alves V. \& De Martinis E.C.P. 2014. Unraveling microbial biofilms of importance for food microbiology. Microbial Ecology. 68(1): 35-46. DOI: 10.1007/s00248-013-0347-4

38 Winkelströter L.K, Tulini F.L. \& De Martinis E.C.P. 2015. Identification of the bacteriocin produced by cheese isolate Lactobacillus paraplantarum FT259 and its potential influence on Listeria monocytogenes biofilm formation. LWT-Food Science and Technology. 64(2): 586-592. DOI: 10.1016/j.lwt.2015.06.014

39 Woo J. \& Ahn J. 2013. Probiotic-mediated competition, exclusion and displacement in biofilm formation by foodborne pathogens. Letters in Applied Microbiology. 56(4): 307-331. DOI: 10.1111/lam.12051

40 Zafar N., Nawaz Z., Qadeer A., Anam S., Kanwar R., Ali A., Mudassar M., Javid M.T., Zafar A. \& Tariq A. 2020. Prevalence, molecular characterization and antibiogram study of Listeria monocytogenes isolated from raw milk and milk products. Pure and Applied Biology. 9(3): 1982-1987. DOI: 10.19045/bspab.2020.90211

41 Zhao T., Podtburg T.C., Zhao P., Chen D., Baker D.A., Cords B. \& Doyle M.P. 2013. Reduction by competitive bacteria of Listeria monocytogenes in biofilms and Listeria in floor drains in a ready-to-eat poultry processing plant. Journal of Food Protection. 76(4): 601-607. DOI: 10.4315/0362-028X.JFP-12-323.

42 Zoz F., Grandvalet C., Lang E., Iaconelli C., Gervais P., Firmesse O., Guyot S. \& Beney L. 2017. Listeria monocytogenes ability to survive desiccation: influence of serotype, origin, virulence, and genotype. International Journal of Food Microbiology. 248: 82-89. DOI: 10.1016/j.ijfoodmicro.2017.02.010 